\title{
Migraine and Autism Spectrum Disorder: A Shared Hereditary Basis [Letter]
}

\author{
Abdul Moiz Sahito \\ Dow Medical College, Karachi, Pakistan
}

Correspondence: Abdul Moiz Sahito Dow Medical College, Karachi, Pakistan Tel +92-3313682059

Email abdul.moiz19@dmc.duhs.edu.pk

\section{Dear editor}

I have read the review article entitled "Exploring the Hereditary Nature of Migraines" by Bron et al published in Neuropsychiatric Disease and Treatment. ${ }^{1}$ I congratulate the authors on the successful publication of this informative review article and would like to make some contributions.

The article discussed the pathophysiology of migraine in association with certain allelic variations in the genome. The review article gave a detailed account of Monogenic Forms of Migraine including the common gene variants that are associated with each form.

Although the article provided multiple hereditary aspects of migraine, I think the association of migraine with Autism Spectrum Disorder (ASD) should have been included. Several studies have been conducted that study migraine in relation to other pathological conditions highlighting a common genetic susceptibility. The meta-analysis conducted by Malik et al indicates shared genetic susceptibility to migraine and ischemic stroke (IS), with particularly strong overlap between Migraine without aura (MO) and both Large Artery Stroke (LAS) and Cardioembolic Stroke (CE) pointing towards shared mechanisms. ${ }^{2}$ The findings in another meta-analysis conducted by Adewuyi et al confirm the comorbidity of endometriosis and migraine and indicate a non-causal relationship between the two traits, with shared genetically controlled biological mechanisms underlying the co-occurrence of the two disorders. ${ }^{3}$ These studies show that several conditions occur in association with migraine more often than it is believed. The association of migraine and ASD has the potential to be studied because both conditions share some common pathophysiological and genetic basis including calcium channel mutations and polymorphisms. ${ }^{4}$ The review article by Vetri also concluded that Autism and migraine share common pathophysiological changes: neurotransmission dysregulation, especially of the serotoninergic system; altered immune response causing neurogenic neuroinflammation; abnormal findings especially in the cortical minicolumn organization and in the dysfunctional gut-brain axis; shared susceptibility genes. ${ }^{5}$

Therefore, it has become evident that the association of migraine with ASD warrants a thorough investigation to highlight their comorbidity correctly and completely. This will allow new preventive measures and treatment methods to be developed for both conditions and can lead to a proper understanding of their genetic basis.

\section{Disclosure}

The author reports no conflicts of interest in this communication. 


\section{References}

1. Bron C, Sutherland HG, Griffiths LR. Exploring the hereditary nature of migraine. Neuropsychiatr Dis Treat. 2021;17:1183. doi:10.2147/ NDT.S282562

2. Malik R, Freilinger T, Winsvold BS, et al. Shared genetic basis for migraine and ischemic stroke: a genome-wide analysis of common variants. Neurology. 2015;84(21):2132-2145. doi:10.1212/ WNL.0000000000001606
3. Adewuyi EO, Sapkota Y, Auta A, et al. Shared molecular genetic mechanisms underlie endometriosis and migraine comorbidity. Genes. 2020;11(3):268. doi:10.3390/genes11030268

4. Nanou E, Catterall WA. Calcium channels, synaptic plasticity, and neuropsychiatric disease. Neuron. 2018;98(3):466-481. doi:10.1016/ j.neuron.2018.03.017

5. Vetri L. Autism and migraine: an unexplored association? Brain Sci. 2020;10(9):615. doi:10.3390/brainsci10090615

Dove Medical Press encourages responsible, free and frank academic debate. The content of the Neuropsychiatric Disease and Treatment 'letters to the editor' section does not necessarily represent the views of Dove Medical Press, its officers, agents, employees, related entities or the Neuropsychiatric Disease and Treatment editors. While all reasonable steps have been taken to confirm the content of each letter, Dove Medical Press accepts no liability in respect of the content of any letter, nor is it responsible for the content and accuracy of any letter to the editor.

\section{Publish your work in this journal}

Neuropsychiatric Disease and Treatment is an international, peerreviewed journal of clinical therapeutics and pharmacology focusing on concise rapid reporting of clinical or pre-clinical studies on a range of neuropsychiatric and neurological disorders. This journal is indexed on PubMed Central, the 'PsycINFO' database and CAS, and is the official journal of The International Neuropsychiatric Association (INA). The manuscript management system is completely online and includes a very quick and fair peer-review system, which is all easy to use. Visit http://www.dovepress.com/testimonials.php to read real quotes from published authors.

Submit your manuscript here: https://www.dovepress.com/neuropsychiatric-disease-and-treatment-journal 